\title{
Civilisations
}

Revue internationale d'anthropologie et de sciences

humaines

$39 \mid 1991$

Japon : les enjeux du futur

\section{Socio-cultural backgrounds of Japanese interpersonal communication style}

\section{Youichi Itoh}

\section{(2) OpenEdition}

\section{Journals}

Electronic version

URL: https://journals.openedition.org/civilisations/1652

DOI: 10.4000/civilisations. 1652

ISSN: 2032-0442

\section{Publisher}

Institut de sociologie de l'Université Libre de Bruxelles

\section{Printed version}

Date of publication: 30 October 1991

Number of pages: 101-128

ISBN: 2-87263-044-9

ISSN: 0009-8140

Electronic reference

Youichi Itoh, "Socio-cultural backgrounds of Japanese interpersonal communication style",

Civilisations [Online], 39 | 1991, Online since 06 July 2009, connection on 07 December 2022. URL:

http://journals.openedition.org/civilisations/1652 ; DOI: https://doi.org/10.4000/civilisations. 1652

All rights reserved 


\section{SOCIO-CULTURAL BACKGROUNDS OF JAPANESE \\ INTERPERSONAL COMMUNICATION STYLE}

Youichi ITO

\section{Introduction}

There exist probably more than one hundred books and articles written on the unique characteristics of Japanese interpersonal communication style. Many of them are devoted to the comparison between Japanese and American communication styles. Some of them are empirically based, but many are based on observations, episodes, proverbs and sayings, insights, and personal experiences. According to an emperical study by Barn lund (1975: 50-54), both Japanese and American respondents thought that Japanese are "reserved, formal, silent, cautious, evasive, and serious" while Americans are "self assertive, frank, informal, spontaneous, and talkative". In this study a sharp contrast was empirically discerned between Japanese and American interpersonal communication styles.

Compared with the contrast between Japanese and Americains, comparisons between other combinations such as between Japanese and Europeans, Japanese and Chinese, Europeans and Americains, etc. seem far smaller. Several reasons are conceivable for this. First, Japan and the United States are neighboring countries across the Pacific Ocean, and there are massive flows of people and information between the two countries. Second, Japan and the United States are both politically, economically and culturally influential in the world, and many people are interested in the differences (and similarities) between these two powers. Third, many people seem to think that Japan and the United States are the two 
extremes as far as the interpersonal communication style is concerned.

As for the third point, however, I am not sure. Although I admit that Japan's position would be close to an extreme end on the continuum, I am not sure about the United States. If I were a respondent, I would give higher scores to Australians and South and West Asians such as Indians, Pakistanis, Iranians, Arabs and Jews on "self assertive" and "talkative" scales. I had this impression when I travelled in Australia and South and West Asian countries or when I was with people from those countries at international conferences or symposiums. People from those countries were often more aggressive, decisive, opinionated, talkative than Americans and often dominated international conferences. It is often said in East Asia that a good conference moderator means a person who makes Japanese and Koreans speak more and make Indians and Pakistanis speak less. Although I do not have empirical data, I have always had an impression that the distances between Japanese and Australians, Indians, Pakistanis, or Iranians are probably greater than that between Japanese and Americans as far as the aggressiveness and talkativeness in communciation behavior are concerned.

Naozuka (1980) translated into English many day-to-day conversations by Japanese housewives that she thought uniquely Japanese and investigated the reactions of subjects composed of many nationalities. One of the findings of this study was that Northwest Europeans, especially British, were much less resistant againts hinting and circumlocutions used in Japanese daily conversations than Americans and some other groups such as South Asians and Latin Americans. Toyama (1976 : 302-306) points out that Japanese and British resemble each other in that they both dislike talkativeness or have an inclination to silence and prefer reserved expressions to 
exaggerated expressions. These findings and observations support my personal impressions that the distance between Japanese and Northwest Europeans is much closer than assumed in popular "East versus West" theories.

Probably because Japanese are close to an extreme end of the continuum and are always expected to understand tacit messages as described later, Japanese are generally quite sensitive to the difference in communication styles. Japanese tend to measure the cultural distance between a foreign country and Japan by interpersonal communication styles. When I visited Sri Lanka as the head of the Japanese government mission for an economic and technical aid program, we made interviews with several Japanese business managers stationed in Sri Lanka. One of them who had just been transferred from India told us happily, "Do you know Sri Lankans are much more like us ? Here, after the meeting, some employees often come to me and say, 'I wanted to say this at the meeting, but could not. My true feeling is so and so'. This never happens in India".

A Japanese novelist, Hotta (1957) once wrote that East of Burma modest silence is a virtue whereas West of Burma eloquence is a virtue. Haga (1979 : 19) also wrote as follows.

In the Eurasean land mass, there is a contrast between East and Southeast Asia including Japan which are reticent societies and India, Arab countries and Europe which are talkative societies.

Clark (1977) sees the world in a slightly different way. According to him, countries belonging to the Eurasian land mass including China, India, Korea and Vietnam are "ideological societies". On the other hand, island countries detached from the Eurasean land mass such as Japan, the Philippines, Indonesia, and small islands in Southern Pacific are all "human relations societies"1. People in ideological societies 
tend to be self assertive, frank and talkative whereas people in human relations society tend to be reserved, silent and cautious.

\section{Major Theories to Explain the Differences}

\section{(1) Homogeneous Society Versus Heterogeneous Society}

There are homogeneous societies and heterogeneous societies in the world. Homogeneous societies consist of people with basically the same racial, cultural and historical backgrounds whereas heterogeneous societies consist of people with different racial, cultural and historical backgrounds. In homogeneous societies, because people share basically the same values, beliefs, language and customs, people do not have to define concepts, "ideologize" their thoughts and debate with others. Homogeneous societies are like families. The prototype of communication style in homogeneous societies is communication among family members. It has two main characterisitics (1): Language tends to be ambigous. Just like family members can understand each other with ambiguous expressions, people in homogenous societies tolerate ambiguity because they share the same culture. According to Kunihiro (1976 : 19-20), a typical Japanese expression is, "Please do that like that". In Japan, however, "that" will be done like that as a result without further explanations (2). Non-verbal communication plays more important roles than in heterogeneous societies. Just like among family members, people in homogeneous societies are expected to sense and understand unsaid messages. In Japan there is a proverb saying "Me wa kuchi hodo ni monoo ii " (Eyes tell as much as mouth). This is a typical example. On the other hand, in heterogeneous societies, people always have to define concepts and clearly explain what they are trying to say. Circumlocutions do not work because people do not share the same cultural and linguistic backgrounds. 
The communication culture in homogeneous societies is what Hall (1976) described as "high-context culture" and that of heterogeneous societies corresponds to "low-context culture". Gudykunst and Ting-Toomey (1988) relates "high-context culture" with "collectivistic" culture and "low-context culture" with individualistic culture. However, "high-context culture" may be a characteristic of homogeneous societies and "lowcontext culture" may be that of heterogeneous societies. Many Japanese scholars have tried to explain the characteristics of Japanese communication culture from this perspective (See, for example, Kato, 1973; Kunihiro, 1973, 1976; Kitamura, 1977; Toyama, 1976; Suzuki, 1980). A problem with this theory is that there are several homogenous societies in Europe like Sweden, Norway and Ireland and many heterogeneous societies in Asia such as Indonesia and Malaysia. It is very probable that the Indonesian communication style is more similar to the Japanese style than the Swedish style is.

\section{(2) Influence of Religion}

While Christianity and Islam encourage active and sometimes aggressive ways of life, Oriental religions such as Buddhism, Confucianism, and Taoism all encourage passive, quiet and modest ways of life. In the case of Confucianism, it emphasizes politeness, respect for seniority, harmony and social order. Buddhism denounces secular desires, emphasizing peace, jihi (love and mercy) and harmony, especially harmony with nature. These teachings tend to supress frank expression of individual opinions. For example, Ju (1986) and Chu (1988) emphasize the strong influence of Confucianism on the Chinese communication culture. According to Chu (1988: 127-128) :

In Chinese Confucian culture, authority is respected and harmony is cherished. This respect for authority calls for the obedience of specific rituals in communication between elders and their juniors and between superiors and their subordinates. Choice of words and 
salutations so as to show respect and to maintain the hierarchy of social order can be very tedious and difficult. Respect for elders and superiors has also influenced the expression of opinion in public. To avoid offending elders or superiors, dissenting opinions are more often than not withheld.

Among peers, harmony takes precedence over respect for authority. To maintain harmony, conversations are not only carefully worded but also calculated for this purpose. Dissenting opinions are avoided as well.

Both Ju (1986) and Chu (1988) claim that these characteristics in the Chinese interpersonal communication style have not changed even under the Communist rule.

On the other hand, according to Barnlund (1975:165), the "United States resembles a nation of missionaries". Each individual has his or her own opinions regarding many kinds of issues and is highly motivated for persuading other people and change their opinions.

The urge to speak out, to express personal conviction, to take a stand, to influence others is so compelling that automobile bumpers carry arguments to and from work, proclamations cover the surfaces of buildings, political posters hang from house windows, annoucements overflow bulletin boards and kiosks, grafitti fill up the walls of public toilets, even lapel buttons carry opinions. It is as if there were not enough times, not enough platforms, not enough channels for personal expression (Barnlund, 1975 : 165).

The attitudes and behavior certainly remind people in nonChristian countries such as Japanese of that aggressive Christianity.

(3) Individualistic Society Versus Collectivistic Society

This theory is dominant among Western scholars. Many Western scholars believe that communication styles are deeply 
related to what extent the society is devoted to individualism or "collectivism". One of the serious problems with this theory is that individualism or collectivism are not neutral concepts in Western or non-Western societies. Individualism is now an important part of the mdoern Western ideology. In other words, individualism is a value-laden concept. For westerners individualism has a positive connotation and collectivism has a negative connotation. On the other hand, in non-Western societies, partly due to the reaction against Western propaganda of individualism, individualism has often been equated with egoism and selfishness.

The direct Japanese translation of "individualism", kojinshugi, used to have a strongly negative connotation. It was almost the same as "egoism". After World War Il, however, the connotation has improved depending on the context it is used. If it is used to mean the respect for individual human rights, individual creativity or individuality, it can have a good connotation. In many other contexts, however, it still reminds many Japanese of "selfishness".

The Japanese translation of "collectivism", zentaishugi, usually refers to a dictatorial political system such as ultra nationalism, militarism, Nazism and some kinds of Socialism. Therefore, Japanese never use zentaishugi or collectivism when they try to explain their own system. This psychology is the same as that Western scholars would not like their individualism callend as "egoism". In recent years many new concepts were suggested to explain the Japanese system. Aidagarashugi (relationalism) (Kumon, 1982), Kanjinshugi (contextualism) (Hamaguchi, 1977, 1982), saijinshugi (interindividualism) (Ito, 1989) are such examples. Many other Japanese scholars use shuhdanshugi or "groupism" as a more neutral concept than "collectivism" although we are not sure to 
what extent the word "groupism" sounds neutral to Western ears.

There are three aspects to be noted in individualism. First is that there may be evolutionary relationship between individualism and collectivism. Collectivism may revolve into individualism as industrialization and modernization proceed. This was the case in Europe. Second is that the difference between individualism and collectivism may be related to natural or geographical conditions. As we discuss later, collectivism is more suited to plant agriculture and individualism is more suited to stock farming. This explains why individualism is more predominant in the United States, Canada and Australia than in Europe. Third is that, as already mentioned, individualism is a key concept in western democracy. Therefore, individualism is highly ideological. However, it is difficult to adopt the modern Western democratic political system without accepting individualism at least to some extent. On the other hand, although "collectivism" has often been criticized as legacies of the feudal past, its modern version, i.e., more democratic collectivism that I call "interindividualism" still has merits. Because it minimizes unnecessary interpersonal conflicts and loss caused by them, it contributes to social and political stability and enhancement of group performance. It also prevents personal alienation caused by excessive atomization.

For whatever cause, it is true that individualism tends to make people more self assertive, frank and talkative whereas "collectivism" or "inter-individualism" tends to make people more reserved, silent and cautious.

(4) Human-Relations Society Versus Ideological Society

According to Clark (1977), all human tribes started as homogeneous "human relations societies" where the first 
priority was given to create and maintain good human relations. However, as these tribes expanded, experienced conflict with other tribes and included ethnic minorities, it became necessary for them to make rules and principles and ideologies to justify those rules and principles. Thus, these societies became ideological societies. On the other hand, the tribes that did not experience much inter-tribal conflict remained as relative homogeneous, human relations society. In these societies indentities were easily maintained by common blood or common ancestors. In ideological societies, however, identity through common blood or common ancestors was impossible. Therefore, their ideology became their source of identity.

According to Clark (1977) major countries in the Eurasian land mass including China and India became ideological societies by going through many inter-tribal conflicts, conquests and being conquered. People in the Eurasian land mass and the America and Australia which are extentions of the European civilization therefore have a tendency to stick to rules, principles, ideologies and tend to seek identity in their principles and ideologies.

On the other hand, in island societies detached from the Eurasian land mass such as Japan, the Philippines, Indonesia and South Pacific islands, people have not experienced many severe inter-tribal conflicts in their histories. It is true that there were a number of wars within Japan, but because they were civil wars, people did not have to justify their culture and their cultural identity has never been threatened. In these societies, therefore, people are more loose, tolerant and flexible about rules, principles, religions and ideologies, and tend to seek their identity in common blood. On the other hand, "ideological societies" are more serious, intolerant and rigid about different principles, religions and ideologies but more tolerant to 
different "bood". Japan is a typical example of human relations society. How many years you may live in Japan, however well you may speak Japanese, and even if you are naturalized, you will never be accepted as an insider. You must be born Japanese $^{2}$.

It is true that Japanese are very surprised to see Americans and Europeans adopt children of different races. It is extremely difficult for Japanese to do that. It is far more difficult than interracial marriage. On the other hand, Americans and Europeans are very surprised to see many Japanese celebrate the birth of a child at a Shinto shrine, get married at a Christian church and have a funeral at a Buddhist temple. Why do Japanese do that? It is because the Christian wedding ceremony looks most romantic, the Buddhist funeral looks most solemn, and a Shinto shrine makes Japanese feel nationalistic. Being asked "Why the Buddhist funeral ?", a Japanese answered "I woudn't feel really dead without it".

Clark 1977) thinks that in ideological societies, people tend to be self assertive, opinionated, aggressive and logical because their identity is in their principles, religions and ideologies. On the other hand, in human relations societies, people do not take rules, principles, religions or ideologies that seriously. It is more important for them to create and maintain good human relations and group harmony.

Although Clark was born in England, he spent most of his life in Australia, China and Japan and he speaks Japanese, Chinese and Russian fluently. He is now a full-time professor at a Japanese University (Jochi or Sophia) in Tokyo. Therefore, his theory explains the characteristics of societies in the Asia and Pacific region quite well. Although there are many similarities between China, Korea and Japan chiefly due to Confucianism and Buddahism, most scholars in this region agree that the 
degree of "collectivity" or emphasis on human relations and group harmony is stronger in Japan than in China or Korea.

Kageyama (1988) who studied the business management system in Korea concluded :

As individualistic tendencies are stronger in Korea, there must be some reason behind "harmony" in Korea. Spontaneous harmony and group consciousness as seen in Japan is not easy to create and maintain in Korca... To what extent the Japanese model in business management or industrialization can be applied to Korea is a difficult question faced with Korean government bureaucrats and business leaders.

There is a well-known joke made in Korea. "One Korean can beat one Japanese. However, three Koreans can never be able to beat three Japanese. Why ? It is because three Japanese cooperate, but three Koreans fight with each other".

Also, Chinese and Koreans are obviously more self assertive, frank and talkative than Japanese. However, when Chinese and Koreans are compared with Filipinos and Indonesians, Clark's theory may not be as convincing as in the case of the comparison with Japanese. Filipinos and Indonesians have "tropical temperament" that makes them talkative.

(5) Influence of Climate

Haga (1979: 19) writes, "if you take a train in Tokyo and go to westward" (actually, "westward" means southwest in Japan), "you will notice that the train gradually becomes noisy". Most Japanese will agree that people from northern part of Honshu such as Aomori, Akita, Yamagata and Iwate prefectures are reserved, silent and patient whereas people from Kyusku and Okinawa are talkative, expressive, 
passionate, and short-tempered. This is a sterotyped image, but since everybody has believed this for many generations, there may be some truth in it. For example, spectators of baseball games or horse racing sometimes become excited and fist fights or riots take place. Interestingly, this kind of incident always occurs in southern parts of Japan such as Fukuoka and Hiroshima and seldom occurs in northern parts of Japan like Sapporo or Sendai.

In Europe, Italians and Spaniards are considered to be more talkative, expressive, passionate and short-tempered than Swedish and Norwegians. In Asia, Filipinos, Thais, Indians and Pakistanis are considered to be more talkative, expressive, passionnate and short-tempered than Chinese, Japanese and Koreans. In Asia, people joke, "bind the hands of Indians, then they cannot talk". Are these only unscientific stereotyped images that are not true at all ?

The difference between northern Japan and southern Japan has often been explained that in northern Japan temperature in winter is so low that people try not to open their mouths so as to not lose heat. This explanation is rather humorous, but there may be some truth in it because northern Japanese dialects require less mouth movement than southern dialects. In addition, high temperature may stimulate people's motivation to talk.

(6) High Population Density Versus Low Population density

Reischauer (1977) points out that the land productivity of grain in East Asia where the climate is warm and humid has always been much higher than that in West Asia and Europe where the climate was dry and cold. This explains why the density of population has always been higher in East Asia than in West Asia and Europe. This also explains why these values 
are relatively more respected in Europe than in North America or Australia.

All six theories discussed above have strengths and weaknesses. There are a number of societies that cannot be explained by any one of these theories. Communication styles of different societies may be affected by several factors. Here let me add another theory.

\section{Communication Styles and Human Relations in Main Industries}

Many scholars and critics have proposed that Japanese cultural characteristics especially those related to human relations have to do with the forms of traditional main industries. Isaiah Ben-Dasan ${ }^{3}$ in his bestselling book The Japanese and the Jews (1970) claims that :

The Arabs in the vicinity of Palestine, after scattering wheat seed on the ground, lead their flocks to pasture. When the proper time comes, they return to harvest the grain, then go about other business. Their climate makes wheat raising incidental. In the Philippines, where three rice crops are possible in one year, the people plant and haverst more or less whenever they like. But the Japanese climate and reliance, in the past at any rate, on rice as a staple food combine to create circumstances demanding a much more strictly prescribed, campaign-style agricultural system (Ben-Dasan, English version, 1972 : 45).

Ben-Dasan argues that these differences caused different values and behavioral patterns among West Asia, South Asia and East Asia. For example, Japanese farmers had to plant, transplant and harvest rice according to the strictly prescribed schedule. Few days delay in schedule could mean failure and starvation. Calender and making a schedule were extremely important to Japanese farmers. This made Japanese farmers time-conscious, schedule-conscious and industrious. When Japan started industrialization, these farmers became factory 
workers and their traditional traits contributed a great deal to the success of Japan's industrialization.

Campaign-style agriculture has given the Japanese one more distinguishing trait : a sense of the unity of all the people of the nation... In the Middle Ages eighty-five percent of the population farmed the land. This meant that at any given period of the year, almost everyone was doing the same kind of work. When the season came to transplant the rice seedlings into the paddies, the entire farming population was engaged in that activity. The exigencies of campaign-style agriculture forbade a going-my-ownway attitude. Since hunger and distitution were the certain outcome of such independence, anyone who insisted on adopting it inevetably became a burden on his neighbors (Ben-Dasan, English version, $1972: 49-50$ ).

Ben-Dasan (1970) call Japanese farmers "neighbor farmers". This means that Japanese farmers have traditionally planted rice when their neighbors started to plant, transplanted into the paddies and harvested when their neighbors started to do so. That was the safest way of life. "The exacting schedule imposed by campaign-style rice production" made it important for Japanese farmers to cooperate with eath other. Through mutual cooperation farmers could finish their work in time.

The nomadic way of life in West Asia is completely different. "Able literally to go their own way, owners of flocks of sheep were in the past and are today free to lead their animals over boundless and boundary-less plains of grasslands" (Ben-Dasan, English version, $1972: 52$ ). Therefore, the West Asian life style is characterized by "going my own way" and individualism.

Some people may say that there are many "collectivistic" countries in West Asia and the Arab World such as Iran and Libya. According to Ben-Dasan, however "collectivism" in Japan and that in West Asia are essentially different. Japanese "collectivism" comes from traditional form of production and 
everyday way of life of common people. Therefore, it is "genuine collectivism" or "collectivism from the bottom". On the other hand, "collectivism" in West Asia is "artificial collectivism" or "collectivism from the up". It comes from the necessity for nation-building or the ambitions of political dictators. Anyone desiring to build a modern state in West Asia where "going my own way" and individualism are predominant "must first of all realize that unless the Arab sands are held tightly in the hand, they slide away in all directions" (Ben-Dasan, English version, 1972 : 52). That is why Japan has never needed any charismatic leaders nor unified religion throughout its history but West Asian countries always need them ${ }^{4}$.

According to Ben-Dasan (1970), traditional forms of production in Europe and the Americas had both Japanese "campaign-style agriculture" elements and West Asian normadic elements. He thinks, therefore, that European and American cultures are located somewhere between these two extremes.

Reischauer (1977) and Matsubara (1984) also emphasize how important cooperation was in the Japanese style rice production. They think that these necessities have made Japanese people group-oriented. Matsumura (1984) further thinks that the Japanese communication style that emphasizes harmony derived from customs and beliefs based on rice production.

Nakano (1982) finds a prototype of Japanese organizational communication in meetings called yoriai held in traditional villages in Japan. When something important to the village members occurs yoriai is held and all the attendants are asked to express their opinions. However, discussions or debates are never held in the first meeting. The purpose of the first meeting is that each member knows what other people think about the 
issue. After the meeting, each member thinks at home how a consensus can be made regarding the issue. Through intrapersonal communication and informal communication with close friends, family members, or even competitors, each person is expected to modify his or her opinion and cooperate to create a consensus. Thus, the discrepancies among members are diminished at the second meeting. At the second meeting, people are again asked to express their revised opinions. If there still exist serious discrepancies, the second meeting adjourns without substantial discussions. This process continues until the discrepancies among the members diminish further and a consensus is achieved.

Since the late 19th century, Japan imported many Western political, economic, and social organizations. According to Nakano, however, the decision making process at modern Japanese institutions is basically the same as in traditional yoriai. The National Diet, local legislatures, formal meetings in modern large corporations or labor unions are all places to know other people's opinions and not for substantial discussions or debates. Discrepancies of opinions are filled through informal meetings at bars and restaurants after the meeting. Thus, some important parts of the Japanese decision making process are invisible. This invisible decision making process is called in Japan "duck's paddling". Therefore, the Japanese way of decision making takes times. However, the main purpose of it is to reach a consensus without other confrontation or embarassement in public among group members. This mechanism works in inter-personal communication as well.

When the subject matter is serious, there is only a speaker and a listener and there is no true dialogue in a conversation between two Japanese. Even when the listener does not agree with what the speaker says, he or she seldom makes a counter 
argument especially when the speaker is a senior person because he or she is afraid of embarrassing the speaker. However, the next time these two people meet, the former listener may voice his or her opinion. Then the former speaker is likely to just listen without making a counter argument. After experiencing such interactions several times, both of them will understand the other person's opinion and they may decide to modify their opinions or decide not to talk about that subject any more with that person. Thus, in conversation between two Japanese, the one who first speaks out dominates the conversation.

The pressure for maintaining good human relations and group harmony is so strong that it has often been pointed out that Japanese attitudes are double structured. It consists of tatemae (diplomatic attitude or attitude to meet other people's expectation) and honne (true attitude). In the West, there are some situations in which people say "Please be frank" or "Please be candid". Therefore, double-structured attitudes may not be so uniquely Japanese. However, "Please let me hear your honne" is very frequently said in Japanese conversations especially by senior people to junior people.

Because Japanese attitudes are double structured and they seldom speak out their honne, Japanese have developed sensitivities to infer other people's true feelings and attitudes. This kind of communication is called ishin denshin or "communication by heart". Japanese are also expected to infer or surmise kuuki or atmosphere of the group that they belong to. When Japanese say that a person is "clever", it means he or she can correctly sense and understand unsaid, non-verbal messages. On the other hand, a "dull" person means a person who does not understand the situation until he or she is clearly informed verbally. In other words, Japanese are expected to infer and understand other people's feelings, attitudes and the 
atmosphere of the situation or the group that they belong to without being told verbally. Very often, therefore, a senior person can influence others with only a few words.

The Japanese communication style as described above may be an extreme case even in East Asia. Communication styles in Korea, China and Southeast Asia seem to be closer to the West Asian or European pattern. Although it may sound to be an extreme case, the Japanese communication style may be considered as a prototype or an "ideal type" of the East Asian communication pattern.

While the East Asian and the West Asian, American, or Australian communication styles are two extremes, the European, especially North European, communication pattern seems to be located somewhere between the two. North Europeans are not as silent as East Asians but not as aggressive and outspoken as West Asians, Americans, and Australians. The reason may be that North Europeans have had both East Asian type plant agriculture and West Asian type cattle breeding. The social structure of traditional East Asian, especially Japanese, farming villages are more similar to European farming villages than to West Asian, American or Australian counterparts.

\section{Communication Style and Modern Production Forms}

As a result of the Industrial Revolution, agriculture or cattle breeding in North America, Europe, or East Asia declined and their influence on people's communication pattern has drastically decreased. It is modern economic organizations, particularly private business corporations that have strong influence on people's communication patterns. If modern economic organizations were more similar to each other in North America, Europe and Japan, communication patterns 
among these industrialized areas should become more similar to each other.

Interestingly, however, modern economic organizations in these three major industrial areas inherited characteristics of their previous major industries. In North America, managers and workers both move from one company to another very easily and frequently. In Japan, neither managers nor workers freely move from one company to another. Europe again seems to be in the middle between these two extremes. Therefore, basic communication patterns did not change in these industrial areas despite that major industries have changed from plant agriculture or cattle breeding to large-scale manufacturing and service providing.

Modern economic organizations are playing survival games domestically and internationally. Strong and efficient companies survive and weak and inefficient companies disepear from the market. Due to "Johoka" or informisation, this survival game is becoming more and more international. In this competition process, any strengths or secrets of strength held by a company tend to be imitated by its competitors. Therefore, it is very likely that the differences that exist between North American, European, and Japanese economic organizations will decrease toward the future.

Until twenty some years ago, Western and Japanese experts both believed that almost all the Japanese or Asian cultural characteristics were legacies of their feudal past. People thought that as Japan became modernized, Japan would become more and more like the United States. Communication experts thought that as Japan became modernized, the Japanese communication pattern would become more similar to the North American pattern. However, we are not sure any 
more. A major reason is Japan's economic strength, social and political stability and relative economic equality.

If some Japanese cultural characteristics contribute to economic strength, social and political stability and relative economic equality, Japanese will try to preserve the characteristics and other nations may try to imitate them. Even if they do not imitate, they will be influenced by the idea.

For example, nowadays American company executives are criticized by Americains for paying too much attention to shortterm profits and do mot pay enough attention to long-term profits. A reason why American managers are more concerned with short-term profits than long-term profits are because they are not sure where they will be ten years later. Some of them plan to sell themselves higher to another company by bringing a huge short-term profit to the company. That action, however, may be harmful to that company's long-term interest. If these practices are changed or modified in the future so that American managers become more concerned with long-term interests, it may be considered in a broad sence as Japanese influence.

According to the latest news report, 2.400 workers of a Japanese automobile company in the United States (Nissan U. S.A. in Tennessee) voted against the proposal to join the United Automobile Workers Union (UAW) (Asahi Shimbun, 1989; Sankei Shimbun, 1989). This is reportedly the second failure for UAW after the Honda factory in Ohio. The basic idea behind the traditional trade relations in the United States has been confrontation between managers and workers based on strict interpretations of contracts and laws. For managers and stock holders, workers are just one of the resources for production. For workers, the company is just a place to earn money and not more than that. 
The Japanese approach is based on the idea that managers and workers belong to the same group sharing the same destiny. If the company succeeds, managers, stock holders and workers all profit, but if it fails, everybody suffers. A work place is not just a place to earn money. It is more than that. Harmony, good human relations in the company, mutual trust, and the feeling of "togetherness" among workers and managers are far more important than interpretations of contracts and laws. One of the most important abilities needed for the top management is the creation and maintenance of this atmosphere in the company. Layoff and discharge for the company's reason harms the mutual trust between managers and workers. Therefore, Nissan U.S.A. and Honda U.S.A. both promised that they would never lay off or fire workers for the company's reason. This is a major reason why American workers in these companies chose their companies and rejected UAW. Many experts have pointed out that the so-called "Japanese management" works only in homogeneous societies like Japan. However, cases in Nissan and Honda in the United States may indicate that the Japanese approach, at least in business management, may be more universal than used to be imagined in the past. For whatever cause, the collectivistic" or inter-individualistic" approach in business management seems to be penetrating in a typical heterogeneous society like the United States.

An American expert on business management told me that the old American management philosophy such as Taylorism or McNamaraism that pursued rationalism to the extreme by treating factory workers like parts of a machine has been almost completely denied in recent years and more humanistic approaches to business management are now emphasized. In a recent public advertisement on American major networks, Walter Cronkite appealed for increased importance of team work and good human relations in American factories using 
Japanese factories as an example. If the horizontal mobility of American managers and workers decrease and team work and human relations in factories become emphasized, the American communciation style may come closer to the Japanese style.

On the other hand, there certainly is a gradual trend in Japan that people are becoming more self assertive, frank and talkative than before. A major reason is "internationalization" of Japan or trend of "globalization". Interactions with foreigners are steadily increasing. Japanese must be able to make foreigners understand their values, beliefs, systems and culture. This is becoming more and more important as Japan increases its influence on world economy and politics. Thirty years ago, people in the world are not so much interested in Japan's behavior. Nowadays, however, many people are concerned. Some people admire but some others are suspicious about Japanese values, beliefs, systems and culture. Japanese should not use ambiguous expressions that are understandable only to fellow Japanese. There are many foreign students in recent Japanese universities. On a graduate level, more than half of students in seminar classes are often occupied by foreign students who are more self-assertive, active and talkative than Japanese students. I always encourage in my classes silent Japanese students to speak out more and express their thoughts and opinions. I sometimes organize debates on social issues in my classes.

Individualism contributes to democratization of the political system and long-term political stability. The idea is also critical for the protection of individual human rights. On the other hand, the "human relations approach" or what I called "interindividualism" contributes to the enhancement of social integration or the feeling of "togetherness", economic equality, social and political stability and enhancement of economic performance. All societies including individualistic and inter- 
individualistic societies can learn from each other's experiences. Developing countries can learn from modern East as well as from modern West.

\section{NOTES}

1. Regarding Clark's theory, some people may ask, "What about island countries in Europe such as the United Kingdom, Ireland and Iceland ?" Unfortunately, Clark does not discuss these countries. As for the United Kingdom where he was born, he apparently thinks that it is too close to the European continent to be culturally independent. However, Iceland is very far from the European continent. May be Clark should examine the culture of Iceland and compare it with island countries in Asia.

2. This may explain a unique role played by the emperor system in Japan. The imperial family symbolizes biological rather than ideological continuity of Japan. That is why it is important for many Japanese in terms of national and cultural identity.

3. Isaiah Ben-Dasan was later revealed to be a disguised Japanese by the name of Shichiro Yamamoto. He is a famous social critic.

4. Some people may ask if Japan before World War II was not ideological and like some West Asian countries at present. Clark (1979 : 180-181) thinks that Japan from late 19th century to history. According to him, in its efforts to survive in the imperialistic period, Japan imitated Western powers and became an ideological country. However, "as a result of the shock of defeat in the war, Japan again returned to its original form a ideological society" (Clark, 1979 : 181). Ben-Dasan will agree with this view. 


\section{REFERENCES}

Asahi Shimbun (1989) "Rohso Kessei ni 'No' : Beikoku Nissan" ("No" to Unionization : Nissan U.S.A.), July 28, 8.

Barnlund, Dean C. (1975) Public and Private Self in Japan and the United states. Tokyo : Simul Press.

Ben-Dasan, Isaiah (1970) Nihonjin to Yudayajin . Tokyo : Yamamoto Shoten. (English translation, The Japanese and the Jews. New York: Weatherhill, 1972).

Chu, Leonard L. (1988) "Mass Communicaiton Theory : a Chinese Perspective", pp. 126-138 in Dissanayake, Wimal (Ed.), Communication Theory : An Asian Perspective . singapore : The Asian Mass Communication Research and Information centre.

Clark, Gregory (1977) Nihonjin : Yunihkusa no Gensen (The Japanese Tribe : Origins of a Nations Uniqueness). Tokyo : Saimaru Shuppankai.

Clark, Gregory (1978) "The Human-Relations Society and the Ideological Society", The Japan Foundation News Letter, VI (3).

Clark Gregory (1979) Yunihku na Nihonjin (Unique Japanese). Tokyo : Kohdan-sha (Gendai Shinsho).

Edelstein, Alex, Ito, Youichi \& Kepplinger, Mathias (1989) Communication \& Culture : A Comparative Approach. New York: Longman.

Gudykunst, William B. \& Nishida, Tsukasa (1983) "social Penetration in Japanese and American Close Friendships", pp. 592-610 in Bostrom, R.N. \& Westley, B. H. (eds.), Communication Yearbook 7 . Beverly Hills, CA : Sage.

Gudykunst, William B. \& Ting-Toomey, Stella (1988) Culture and Interpersonal Communication. Newbury Park, CA : Sage. 
Haga, Yasushi (1979) Nihonjin no Hyohgen Shinri (Psychology of Japanese Expression). Tokyo : Chuo Kohron (Chuhko Sohsho).

Hall, Edward T. (1976) Beyond Culture . New York : Anchor.

Hamaguchi, Eshun (1977) "Nihon Rashisa" no Saihakken (The Rediscovery of "Japaneseness"). Tokyo : Nihon Keizai Shimbun-sha. Paperback edition published by : Tokyo : Kohdan-sha (Gakujutsu Bunko), 1988.

Hamaguchi, Eshun (1982) "Nihonteki Shuhdanshugi towa Nanika (What is the Japanese Groupism ?", pp. 1-26 in Hamaguchi, E. \& Kumon, S. (eds.), Nihonteki Shuhdanshugi . Tokyo : Yuhikaku (Sensho).

Hotta, Yoshie (1957) Indo de Kangaeta Koto (What I Thought in India). Tokyo : Iwanami Shoten (Shinsho).

Inoue, Tadashi (1977) "Sekentei" no Kohzo (The Anatomy of "Appearance"). Tokyo : Nihon Hohso Shuppan Kyokai (NHK Bukkusu).

Ito, Youichi (1989) "A Non-Western View of the Paradigm Dialogues", pp. 173-177 in Dervin, B., Grossberg, L., O'Keefe, B. J. \& Wartella, E. (eds.), Rethinking Communication. Newbury Park, CA : Sages.

Ju, Yanan (1986) "chinese culture : Yesterday \& Today : From a Communication Perspective". Unpublished paper delivered at the First Canberra Conference on International Communication held in Canberra, Australia, December 2-5.

Kageyama, Kiichi (1988) "Nihongata no teichaku ka Ridatsu ka, Magarikado no Kankokushiki Keiei" (Did the Japanese Mangement Style Settled in Korea ? : Korean Management at a Crossroad), Nihon Keizai Shimbun, December 11, 14.

Kato, Hidetoshi (1973) "Nihon Bunka to Komyunikeishon (Japanese Culture and Communication)", pp. 177-195 in Uchikawa, Y., Okabe, K., Takeuchi, I. \& Tsujimura, A. (eds.), Gendai no Shakai to Komyunkikeishon. Tokyo : Tokyo Daigaku Shuppankai. 
Kitamura, Hideo (1977) "Komyunideishon (communication)", pp. 263-285 in Umesao, T. (ed.), Kohza : Hikakubunka, Dai 5 Kan, Nihonjin no Gijutsu (Comparative Culture Series, Vol. 5 : Japanese Technologies). Tokyo : Kenkuy-sha.

Kumon, Shumpei (1982) "Soshiki no Nihongata Moderu to Ohbeigata Moderu", pp. 103-126 in Hamaguchi, E. \& Kumon, S. (eds.) Nihonteki Shuhdanshugi. Tokyo : Yuhikaku (Sensho).

Kunihiro, Masao (1973) "Nihonteki Komyunikeishon no Heisasei (Closed Nature of Japanese Communication)", Nagai, Y. \& Rosovsky, H. (eds.), Nichibei Komyunikeishon Gyappu . Tokyo : Saimaru Shuppankai.

Kunihiro, Masao (1976) Ibunka ni Hashi o Kakeru (Bridging Across Cultures). Tokyo : Eigo Kyohiku Kyohgikai (ELEC Sensho).

Matsubaru, Jiro (1980) "Chiiki Shakai no Ningen Kankei (Human Relations in Local Communities)", pp. 182-193 in Minami, H. (ed.) Nihonjin no Ningen Kankei Jiten. Tokyo : Kohdansha.

Matsumura, Takeo (1984) "Nihonteki Komyunikeishon to Fuhdo (Japanese Communication and Natural Features)", pp. 171-189 in Tsujimura, A. \& Mizuhara, T. (eds.), Komyunikeishon no Shakai Shinrigaku. Tokyo : Tokyo Daigaku Shuppankai.

Midooka, Kiyoshi (1985) "Value Systems and Communication Patterns in Japan". Unpublished paper delivered at the annual convention of International Communication Association (ICA) held in Honolulu, Hawaii.

Nakane, Chie (1967) Tate Shakai no Ningen Kankei. Tokyo : Kohdansha. (English translation, Japanese Society. Berkeley : University of California Press, 1970).

Nakane, Chie (1974) "The Social System Reflected in Interpersonal Communication", pp. 124-131 in Condon, J.C. \& Saito, M. (eds.) Intercultural Encounters with Japan : Communication -- Contact and Conflict . Tokyo : Saimaru Shuppankai. 
Nakano, Osamu (1982) "Nihongata Soshiki ni Okeru Komyunikeishon to Ishikettei (Communication and Decision-Making in Japanese Organizations)", pp. 143-168 in Hamaguchi, E. \& Kumon, S. (eds.), Nihonteki Shuhdanshugi. Tokyo : Yuhikaku (Sensho).

Nakano, Osamu (1984) Komyunikeishon no Kigouron : Joho Kankyo to Atarashi $i$ Ningenzo (Semiotics of Communication : Information Environment and the Image of New Man). Tokyo : Yuhikaku (Sensho).

Naozuka, Reiko (1980) Oubeijin ga Chimmoku Suru Toki : Ibunkaka no Komyunikeishon (When Westerners Become Silent : Communicaton Across Different Cultures). Tokyo : Taishuhkan.

Nishiyama, Sen (1972) Gikai to Rikai (Misunderstanding and Understanding). Tokyo : Saimaru Shuppankai.

Reischauer, Edwin O. (1977) The Japanese . Cambridge : MA : Harvard University Press.

Sankei Shimbun (1989) "Nissan no UAW Kamei o Hiketsu" (Nissan Rejects Joining UAW), July 28, 10.

Suzuki, Takao (1980) "Gengo Seikatsu (Language Life)", pp. 346-364 in Minami Hiroshi (ed.), Nihonjin no Ningen Kankei Jiten. Tokyo : Kohdan-sha.

Toyama, Shigehiko (1976) "Nihongo no Tokushitsu (Characteristics of the Japanese Language)", pp. 301-324 in Takashina, S. (ed.), Kohza : Hikakubunka, Dai 7 Kan, Nihonjin no Kachikan (Comparative Culture Series, Vol. 7 : Japanese Values). Tokyo : Kenkyu-sha.

Tsujimura, Akira (1968) Nihon Bunka to Komyunikeisho (Japanese Culture and Communication). Tokyo, Nihon Hohso Shuppan Kyokai (NHK Bukkusu).

Ueda, Keiko (1974) "Sixteen ways to Avoid Saying 'No' in Japan", Condon, J.C. \& Saito, M. (eds.) Intercultural Encouters with Japan . Tokyo : Simul Press. 


\section{RESUME}

Les organisations économiques modernes ont à faire face à une concurrence de plus en plus forte. Etant donné les progrès des moyens de communication, il est probable que les différences qui existent entre les entreprises nord-américaines, européennes et japonaises vont diminuer à l'avenir. Jusqu'il y a 20 ans, les experts occidentaux et japonais pensaient que presque toutes les caractéristiques culturelles japonaises ou asiatiques étaient des reliquats de leur passé féodal. On pensait que la convergence était inévitable et que les méthodes japonaises de communication deviendraient de plus en plus proches de celles des Etats-Unis. Cependant, nous n'en sommes plus si sûr à présent. De nombreux exemples d'entreprises japonaises à l'étranger semblent montrer au contraire que les valeurs japonaises de communication ont aussi un caractère universel. S'il y a convergence cela veut aussi dire que l'Occident est tout autant réceptif aux valeurs Orientales que le Japon l'a été vis-à-vis de l'Occident. Une raison majeure est la puissance économique du Japon, sa stabilité sociale et politique et une égalité économique relative. 